\title{
Studies on mosquitoes (Diptera: Culicidae) and anthropic environment. 2 - Immature stages research at a rice irrigation system location in South- Eastern Brazil ${ }^{*}$
}

\author{
Oswaldo Paulo Forattini"** Iná Kakitani**, Eduardo Massad ${ }^{* \star *}$, Daniel Marucci** \\ FORATTINI, O. P. et al. Studies on mosquitoes (Diptera: Culicidae) and anthropic environment. 2 - \\ Immature stages research at a rice irrigation system location in South-Eastern Brazil. Rev. Saúde \\ Pública, 27: 227-36, 1993. A relation between a rice irrigation system and mosquito breeding was \\ established in a study undertaken at the Ribeira Valley Experimental Station, from January through \\ December 1992. Flooding favoured Anopheles (Nyssorhynchus) and Culex (Melanoconion) species, \\ while empty paddies condition were propitious to Aedes scapularis and Culex (Culex) species. \\ Compared with a more primitive area of the same region, several species showed high a degree of \\ adaptation to the anthropic environment. Among them, Anopheles albitarsis, a potential malaria vector \\ that breeds in the irrigation system, has shown immature stage production thirteen times higher than at \\ the natural breeding sites. In addition, Ae. scapularis, An. oswaldoi, $C x$. bastagarius, and $C x$. \\ chidesteri presented high levels of synanthropy.
}

Keywords: Ecology vectors. Anopheles. Aedes. Culex. Malaria, transmission.

\section{Introduction}

The epidemiological importance of the relationship between mosquito breeding and irrigated rice cultivation has long been recognized in various regions of the World (Service ${ }^{12}, 1989$ ). A recent comprehensive revision was undertaken by Lacey and Lacey ${ }^{9}(1990)$ who reported on the available data. Concerning the neotropical region, few data are available, perhaps as a consequence of lack of tradition regarding artificially irrigated fields. More recently, observations focusing Aedes and Anopheles have been made (Bisset et al $^{1}, 1989$; Forattini et $\mathrm{al}^{5}, 1989$ ).

In Brazil, attempts have long and increasingly been made to adopt the techniques of irrigated rice cultivation (Keller ${ }^{8}$ 1977; Brito $^{2}$, 1987). Notwithstanding, no recent detailed information is available as to its association with mosquito breeding. Therefore, the present study was car-

\footnotetext{
* $\quad$ Supported by the "Fundação de Amparo à Pesquisa do Estado de São Paulo (FAPESP) - (Grant No 90/3371-6).

** Department of Epidemiology, School of Public Health, University of S.Paulo. Taxonomic and Systematic Research in Medical Entomology Unit of the University of S. Paulo/(NUPTEM) - S. Paulo, SP - Brazil

*** Department of Pathology, School of Medicine, University of S. Paulo, SP - Brazil
}

Reprints: O. P. Forattini - Av. Dr. Amaldo, 715 - 01246-904 S. Paulo, SP - Brazil

Edição subvencionada pela FAPESP. Processo Medicina 93/ 0208-5. ried out as part of a Project planned to undertake systematic research into the relationship between mosquitoes and rice fields. The entire Project will be executed at the southwestern region of S. Paulo State, Brazil and here the first results concerning immature mosquito populations are presented.

\section{Study Area}

Field work was performed at the Ribeira Valley Experimental Station (Campinas Agronomic Institute) in Pariquera-Açu County, S. Paulo State, Brazil. A general description of the site was been published elsewhere (Forattini et $\mathrm{al}^{4}, 1981$ ). Nevertheless, since some time has passed, it is convenient to present another description so as to append new data.

By regional standards, the Station (ES) is a medium-sized farm covering 256 ha, located at approximately $200 \mathrm{~km}$ SE of S. Paulo City, nearly midway to Curitiba (Paraná State), on both sides of the BR 116 highway, geographically corresponding to latitude $27^{\circ} 30^{\prime}$ south. The average annual rainfall is $2.250 \mathrm{~mm} /$ year. The average temperatures are within the $18.0-25.0^{\circ} \mathrm{C}$ range and the relative humidity is steady around $80.0 \%$ (Fig. 1).

The rice husbandry consists of 11 ha of irrigated paddies in which only one crop is grown annually. The irrigation water is tapped from the Jacupiranga river and fed to the rice paddies by means of pumping and drainage trench systems. 


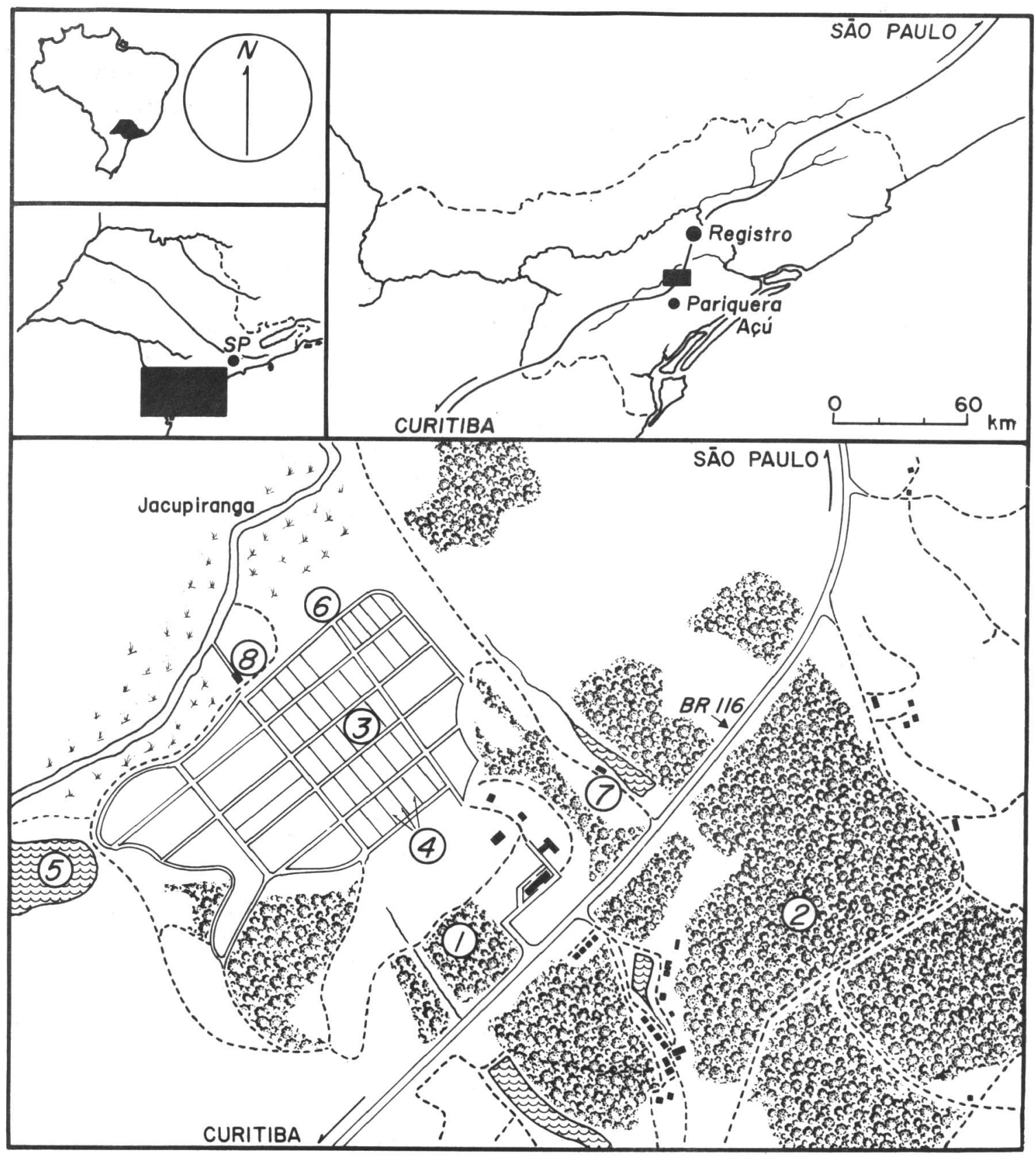

1 - mata residual $A$ (residual wood A)

2 - mata residual $B$ (residual wood B)

3 - tabuleiros irrigados (irrigated paddies)

4 - valas de drenagem (drainage trenches)

5 - lagoa residual (residual pond)

6 - armadilha de Shannon no aberto (exposed Shannon trap)

7 - Sítio Barra do Capinzal (Barra do Capinzal Farm)

8 - bomba de água (water pump)

Figure 1. Map of the study site at the Ribeira Valley Experimental Station (ES), Pariquera-Açu County, S. Paulo State, Brazil.

As tilled land covers $70.0 \%$ of the farm's area, the landscape contains residual wooded areas, vestiges of the primitive natural forest. In addition, three small dams and one residual pond are 
included. Among the several surrounding farms, that named "Barra do Capinzal" is the site of observations to be published later.

Irrigated paddies somewhat different sizes, with grass growing at the edges, thoughout the growing period. Therefore, insolation changes are evident only inside the paddy area, in accordance with the growth of the rice.
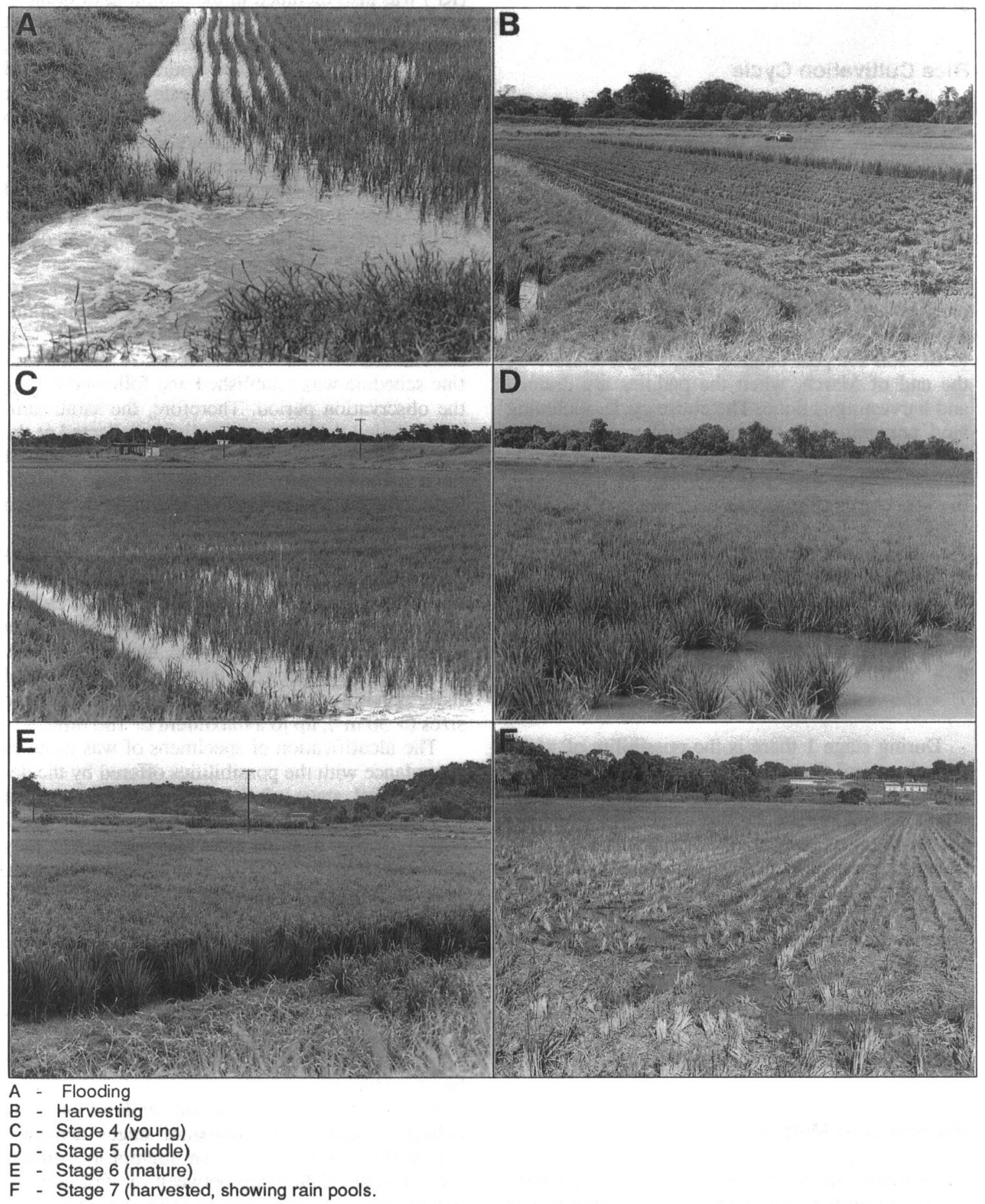

Figure 2. Paddy-field views of the rice cultivation cycle at the Ribeira Valley Experimental Station (ES). 
In order to compare the immature culicid production with that of a different region, collections were also made fortnightly at the previously described Fonte (FT) area (Forattini et $\mathrm{al}^{6}, 1993$ ). Pools, ditches and several others types of surface ground water accumulations were sampled.

\section{Rice Cultivation Cycle}

The cycle of rice husbandry could be properly described as consisting of three main operations, namely, land preparation, nursery transplantation and harvesting. After the soil's resting time, that lasts almost three months, the cycle begins with the preparation of the land that involves the removal of vegetable waste by weeding, burning and subsequent plowing. After being ploughed, the paddies are flooded to grade the terrain. Transplantation is carried out after chemical application to the soil for pest control. The rice is mature by the end of March, when the paddies are drained and harvesting is done. The entire cycle, including land preparation, takes the entire year, with the rice husbandry extending until the March of the following year. Thus this latter may be included in the next stages (Fig. 2, A-F):

1 - Fallow uncultivated.

2 - Ploughed and graded.

3 - Nursery (transplantation).

4 - Young.

5 - Middle (primordial flowering).

6 - Mature (eared).

7 - Harvested.

During stage 1 there is the possibility of widespread natural flooding due to intense rains. The artificial flooding at stage 2 has the purpose of levelling the soil surface. During stages 3,4 and 5, artificial flooding is normally permanent, becoming intermittent at stage 6 . Soil drainage at stage 7 is permanent so as to allow harvesting. Regarding the daily insolation of the covering water sheet, as mentioned above, changes occur inside the paddy according to the growth of the rice. Thus, it may be considered as total at stages 3 and 4, partial at 5 and absent, or with shadow preponderance at the stage 6 . Obviously the insolation becames total again at or after the harvesting stage 7 .

\section{Material and Method}

Immature specimens were collected by means of $500 \mathrm{ml}$ dippers and densities were estimated as an average of the number of individuals per dip.
Sampling was performed fortnightly for a one year (January 1992 - January 1993). At the Experimental Station (ES) collections were concentrated in the irrigation system (IS) comprising the paddies and the drainage trenches. A nearby residual pond (RP) was also included in the sampling in order to compare the production of a permanent breeding place with to that of the system. Once collected, the larvae and pupae were counted and grouped into the sample. The uniform rate of 180 dips per sample was previously established according to the operational daily work schedule.

At the flooded paddies and in the drainage network, collections were made along the borders and inside a previously chosen paddy. In the fields yet to be flooded, dipping collections were made in rain pools. In addition, six paddy soil samples were taken each time, each measuring $15 \times 15 \mathrm{~cm}$ by $3 \mathrm{~cm}$ deep. After being flooded in the laboratory, they were examined twice, ten days apart, and the immature forms were collected. A rotation routine schedule was established and followed during the observation period. Therefore, the same sample included the immature culicids collected at the various habitats (paddies and drainage trenches) of the irrigation system. The same procedure was followed for the residual pond, and dips were taken along its edges.

For the habitats of the Fonte (FT) region, dips were taken proportionally to the estimated breeding surface area. In an attempt to distribute collections regularly, one to six dips were taken from each ground pool classified as small $\left(\leq 50 \mathrm{~m}^{2}\right)$. More than six dips were taken along the edge of those ponds considered to be of medium and large sizes $\left(>50 \mathrm{~m}^{2}\right)$, up to a maximum of 180 dips.

The identification of specimens of was made in accordance with the possibilities offered by the developmental stage of the immature forms. First and second-stage larvae were usually more difficult 10 identify than the older ones and hence, they were put together into the same taxonomic group. In some instances, dissecting or rearing of collected pupae yielded adult males and the examination of their genitalia permitted the identification of the species.

The results refer to all the immature forms collected, without separating larvae and pupae, because the epidemiological aspects, focused here relate to the production of the habitat as mosquito breeding place.

Relate Pearson's correlation analysis monthly collection data of the immature stages densities, was performed with the in an attempt to estimate the eventual relationship between rainfall and immature stage densities. Biodiversity was calculated using the formula proposed by Fisher et $\mathrm{al}^{3}$ (1943) 
and so, independently of the sample size, the diversity index $(\alpha)$ can be estimated as:

$$
S=\alpha \log _{e}\left(1+\frac{N}{\alpha}\right)
$$

where $S=$ number of species

$$
\mathrm{N}=\text { number of specimens }
$$

To estimate the degree of domiciliation of some species at the two studied sites, ES was considered as a higher anthropic environment than FT, where the natural aspect is better preserved. So, the ES/ FT ratio between the collected numbers at each place, was calculated as index of synathropy.

Data about the prevailing rainfall pattern in the region were obtained from the Oceanographic Institute of the University of S. Paulo at the Cananéia Base. These data represent the averages calculated on a monthly basis recorded over the past thirty annual periods 1956-1985 (Instituto Oceanográfico da USP? 1989 ).

\section{Results}

A total of 26,503 immature Culicidae were collected, being $13,349(50,4 \%)$ from ES and 13,154 $(49,6 \%)$ from FT. The identifications are presented in Table.

Irrigation system (IS) - A total of 9,439 immature stages were collected. Since the aim was a preliminary overall knowledge as to breeding sites production, no attempts were made to follow the distribution of densities according to the rice cultivation cycle. Regarding the paddy conditions, only those results obtained in flooded and dry situations are reported here, roughly corresponding to the December-March and April-November periods of 1992. Thus, the IS production was established as the total of the collections made at paddies (whether flooded or non-flooded) and in the network of ditches. The monthly overall distribution of densities is shown in Fig. 3. A total of 7,133 immature forms were collected from those habitats, including 3,420 (47.9\%) Culex (Melanoconion) and 2,153 (30.2\%) Anopheles (Nyssorhynchus). Of these, $578(27.1 \%)$ were identified as An. albitarsis representing $8.1 \%$ of the total dipping collected individuals (Fig. 3).

In the dry condition, a series of isolated pools or even dry areas were created in the paddies and in the drainage ditches as result of the lowering of water levels. That provided the major habitat for mosquito breeding during the empty-paddy period that was coincident with the dry season. In addition, the local residual pond (RP) may be consid- ered as a permanent breeding site. In that period, 667 immature forms were collected, accounting for $1.0 \%$ of the IS total obtained. The higher numbers corresponded to 216 (32.4\%) Aedes scapular- is, 319 (47.8\%) Culex (Culex) species that included $C x$. nigripalpus $(111 ; 17.0 \%)$ and 107 (16.0\%) Culex (Melanoconion) species. Immature stages of Anopheles were poorly represented.

The soil samples of the dry paddies collected and examined during that period, yielded 2,306 larvae, of which 2,205 (95.6\%) were of Culex (Melanoconion) almost all of the Pilosus Group (95.2\%). Aedes scapularis was represented by 99 (4.3\%) larvae and only three were of Anopheles (Nyssorhynchus) species.

The IS production was concentrated in the January-April period when paddies are normally flooded and the drainage trenches exhibit stable water levels. The peak was recorded in January/ February when 4,344 (6.0/dip) were collected, including 1,625 (2.2/dip) Anopheles (Nyssorhynchus). An. oswaldoi was absent from these at that period and was found only from May to November, when 121 specimens were collected, suggesting that smaller water ponds are the prefered breeding sites for this mosquito.

Residual pond (RP) - A total of 3,911 immature culicids were collected. The monthly density distribution is shown in Fig. 4, compared with that of the IS, in which the species reared from soil samples (Ae. scapularis and the Pilosus Group of Melanoconion s.g.) were not computed. Of these specimens, $2,636(67.4 \%)$ were Culex (Melanoconion), 770 (19.7\%) Culex (Culex) and 206 (5.3\%) Anopheles. No representatives of the Pilosus Group were collected and $C x$. chidesteri was the most common among the Culex s.g. (63.5\%) and An. albitarsis represented $28.1 \%$ of the anophelines collected.

Fonte (FT) - At the breeding places of this site, 13,154 immature specimens were collected. These included 11,086 (84.3\%) Culex (Melanoconion), 991 (7.5\%) Culex (Culex) and 496 (3.7\%) Anopheles (Nyssorhynchus), in addition to other species collected in smaller numbers. The monthly density distribution was approximately that of the first group of culicids, as shown in Fig. 5, evidencing a similar trend to that of Anopheles. Concerning Nyssorhynchus s.g., collections showed 223 (45.0\%) Argyritarsis and Albimanus Sections, 206 (41.6\%) An. strodei, 49 (0.1\%) An. albitarsis, in addition to other groups represented in smaller numbers.

Biodiversity- Considering the 44 species identified (Table), the comparison of the biodiversities as between ES and FT, resulted in an overall index of 6.0 , and with the index of 5.0 for each one, with 
Forattini, O. P. et al.

Rev. Saúde Pública, 27(4), 1993

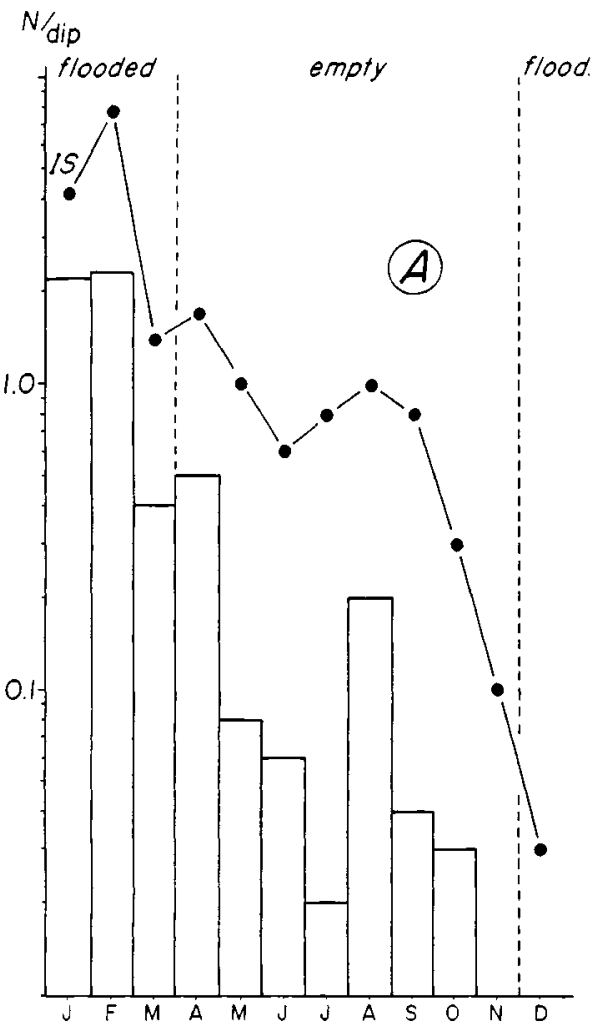

$N /$ dip
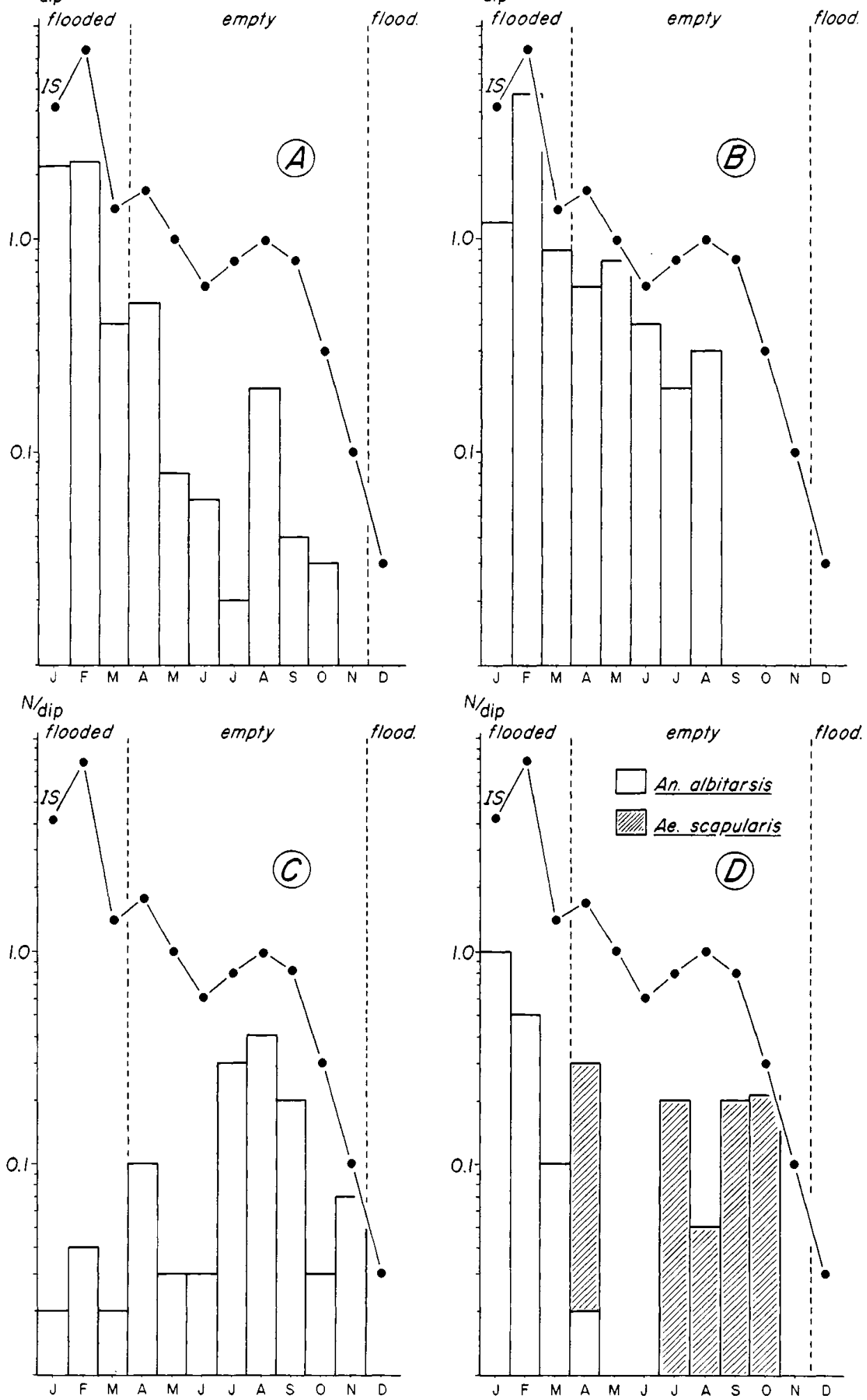

$N /$ dip

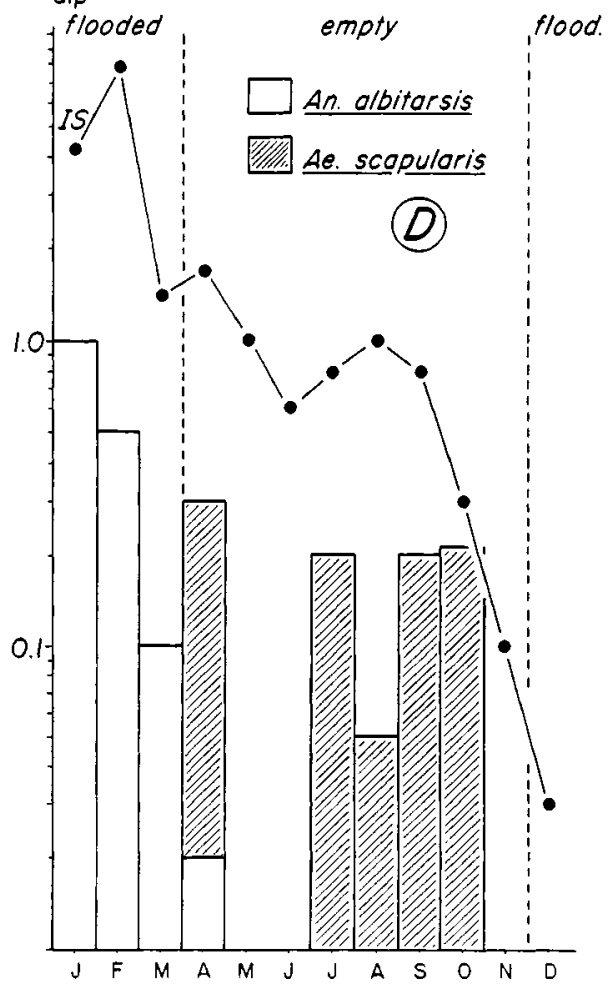

Figure 3. Monthly immature stage densities at the location of the ES irrigation system (IS), from January 1992 through December 1992. Bars represent species and groups. A - Anopheles; B - Culex (Melanoconion); C - Culex (Culex); D Aedes scapularis and Anopheles albitarsis. 
Number/dip

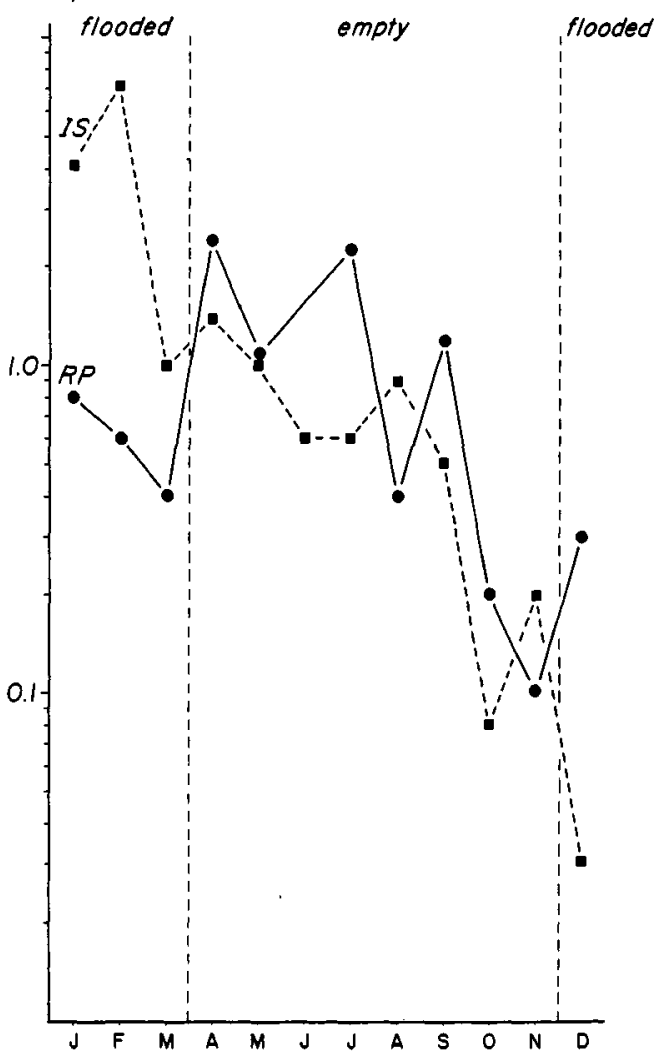

Figure 4. ES monthly immature stage densities at the residual pond (RP) and irrigation system (IS). In these the data regarding the species that were found to be predominant in the soil samples (Ae. scapularis and $C x$. (Melanoconion)) Pilosus Group are not computed.

no quantitative differences. Nevertheless, specific indexes were obtained for An. albitarsis and Nyssorhynchus s.g., besides Aedes scapularis, Culex chidesteri, several $C x$. (Melanoconion) species and other taxonomic categories.

\section{Discussion}

It was possible to obtain a general pattern of Culicidae breeding in the rice irrigation system (IS) and to compare it with more permanent breeding sites (RP and FT). The cycle of rice cultivation by artificial irrigation at ES, has already been described (Forattini et al ${ }^{5}, 1989$ ). The flooding period lasts from December to April, with a few short drainage interruptions, usually in February, during rice germination of the rice. In 1992, paddies were definitively drained in March and harvested at the end of this month. New flooding started at the end of December and the first days of January. The IS flooding period coincides ap-

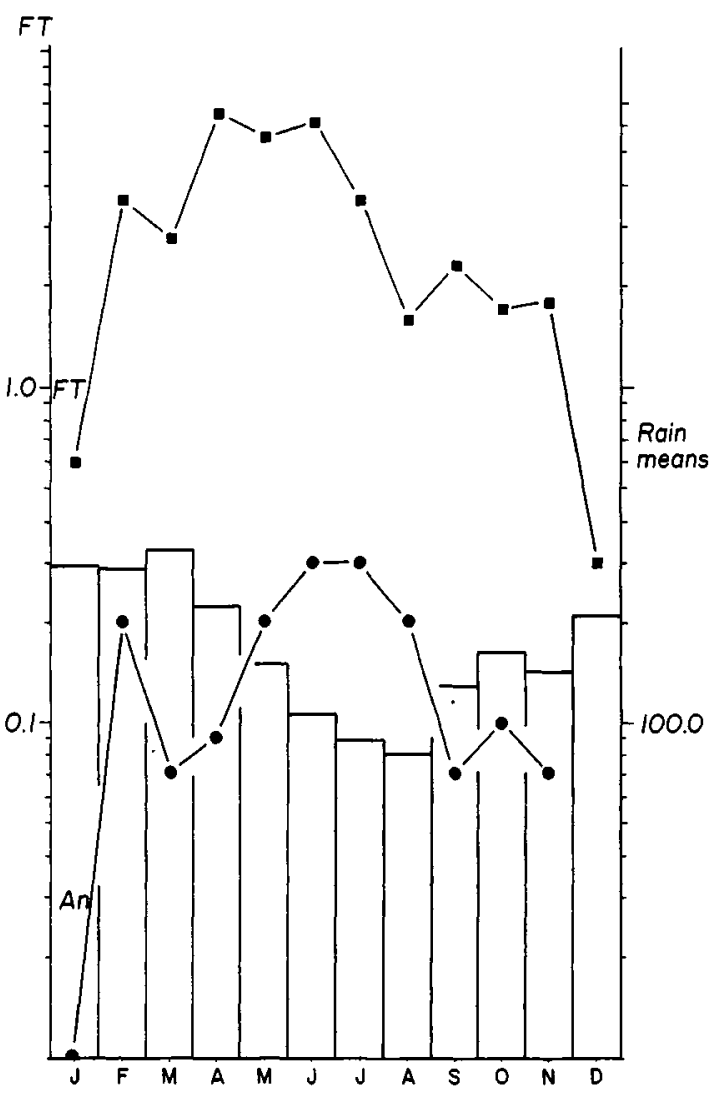

Figure 5. Monthly immature stage densities at FT, excluding those of Anopheles. Bars represent the mean monthly rainfall.

proximately with the regional heavy rainy season. For this reason, the abundance of immature stages was not correlated with rainfall, even at FT, a site with no irrigation system. Only at IS was a significant correlation found $(r=0.62 ; P<0.05)$. However, this could be attributed, rather to the influence of seasonal temperature. The data obtained at FT showed an inverse tendency, probably related to a greater production of Culex (Melanoconion) and $C x$. (Culex) species breeding in ditches and pools with small amounts of water and a low production of Anopheles (Fig. 5).

The mosquitoes' breeding performance in the irrigated rice fields, should be considered as due to the influence of large or small, and permanent or transient features of the IS annual cycle. Rice paddies and drainage ditches can influence mosquito production in two ways: One of them is the large and almost permanent breeding places that remain flooded for at least three or four months. The second the transient nature of the pards, that can become empty or dry, and with rains creating isolated pools, so allowing the hatching of eggs previously laid. Nevertheless, the most productive 
Forattini, O. P. et al.

Rev. Saúde Pública, 27(4), 1993

Table. Immature Culicidae collected at the Experimental Station (ES) and at the Fonte (FT) sites, from January 1992 through January 1993.

\begin{tabular}{lllll}
\hline Taxonomic Categories & ES & Fr & Total \\
\hline
\end{tabular}

Species Identified:

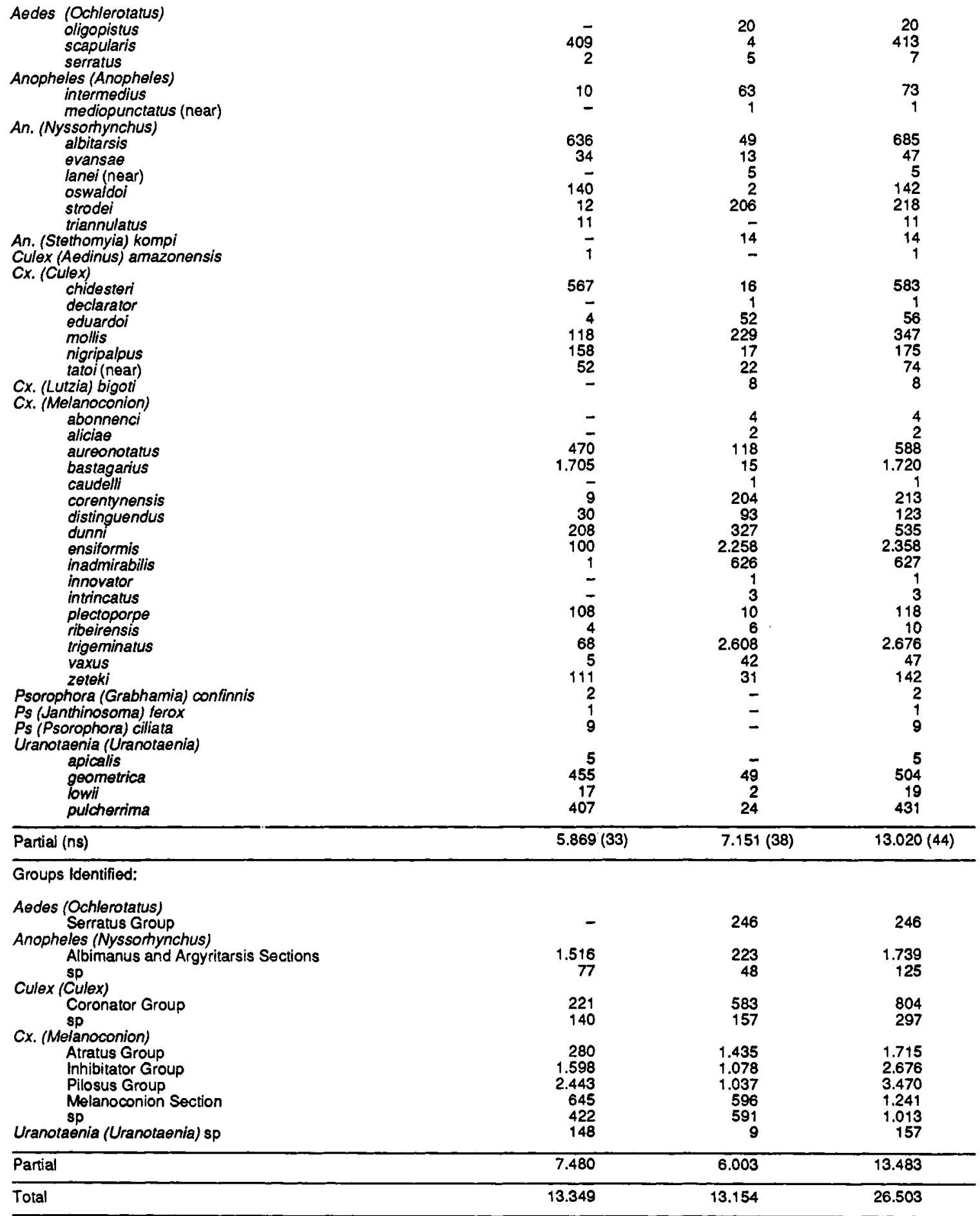

(ns) - Number of species. 
period occurred during the IS flooding, when paddies provided a convenient environment for mosquito breeding. Moreover, this occurs throughout the summer, with an average air temperature fluctuating around $25^{\circ} \mathrm{C}$, increasing adult activity. Under these circunstances, Culex (Melanoconion) and Anopheles (Nyssorhynchus) were greatly favoured, accounting together for more than $78 \%$ of the immature stages collected. An. albitarsis particularly represented $8 \%$, and $27 \%$, considering all the Nyssorhynchus s.g. At the RP, a large natural breeding site, this species represented $28 \%$ of the Anopheles. The marked differences between these results with those obtained at FT are noteworthy if we consider that in FT Nyssorhynchus s.g. was poorly represented and An. Albitarsis was practically inexistent.

During the empty paddies period, the IS general production fell to low levels, as shown Fig. 3 . This was particularly evident for most Culex (Melanoconion) and Anopheles. Otherwise, some of these mosquitoes seem to be favoured by dry conditions. This was true of the Pilosus Group of $\mathrm{Me}$ lanoconion s.g. that furnished a large numbers in the soil samples. These culicids lay resting eggs on moist substracts rather than in masses or rafts on water as do other $C$ ulex species. These eggs are resistant to partial drying, remain viable provided there is some humidity and hatch when subsequent flooding occurs (Mattingly $\left.{ }^{10}, 1976\right)$. Among the representantives Nyssorhynchus s.g., An. oswaldoi also increased at this period, probably as a consequence of its preference for small pools. Culex (Culex) species appeared predominantly at the dry period. The pools littered with the decomposing vegetable matter remaining after this harvesting, together with small quantities of water, were more favourable conditions for these mosquitoes. Aedes scapularis, as a culicid with a marked synanthropic behaviour, was collected only during the period when the IS was dry with the advantage of large of soil for laying eggs. Comparing the mosquito production with that of An. albitarsis, the alternation of both densities over the year was clear. Comparing the IS and RP productions, as shown in Fig. 4, of flooding influence also became evident. At the permanent breeding place, represented by RP, the influence of the dry period was probably limited to the variation of the air temperature, rather than to rainfall.

Despite the lack of quantitative differences between ES and FT biodiversities, specific ones were quite evident, as shown in Table. With regard to the species Aedes scapularis, An. oswaldoi, Cx. chidesteri and An. albitarsis the collection ratio ES/FT were 102.2, 70.0, 35.4 and 13.0, respectively. Among $C x$. (Melanoconion) species the general ratio was 0.7 but, when $C x$. bastagari$u s$, was considered separately that index was 113.7. So, it would seem appropriate to consider these culicids as hemisynanthropes, their adaptation level being related to the human environment (Povolny ${ }^{11}, 1971$ ). From the epidemiological point of view as regard potential malaria transmission, the total Nyssorhynchus s.g. species presented a ratio of 3.0 meaning that, under the conditions of the present research, the anthropogenic environment studied was at least three times more attractive for some species of this group than the more natural one. Among them, the most favoured by the artificially irrigated and flooded rice paddies were An. oswaldoi and An. albitarsis.

\section{Conclusions}

Some data, resulting from a preliminary exploratory study made at the same site (ES) as here reported, have already been published (Forattini et $\left.\mathrm{al}^{5}, 1989\right)$ on that occasion the observations were restricted to adults specimens caught by CDC miniature traps. The results revealed the dominant presence of Aedes scapularis and the almost total absence of An. albitarsis. Nevertheless, the catches were carried out during the May-September period that, as the present results show, is quite favourable to the first of those species mosquitoes (Fig. 3). So, the results obtained from the immature collections here reported, explain those earlier published data satisfactorily.

As a main conclusion, may be said that, during the annual rice cultivation cycle in the Ribeira Valley, An. albitarsis and Ae. scapularis production alternates in accordance with the sequence wet and dry seasons. Other mosquitoes, such as many representatives of Culex (Melanoconion), are favoured by the flooding of the rice puddies and, as a consequence, they present higher density levels. The synanthropic indices presented by these species suggests that they are adapting successfully to the human environment.

FORATTINI, O.P et al. [Estudos sobre mosquitos (Diptera: Culicidae) e ambiente antrópico. 2 - Pesquisa de formas adultas em sistema de irrigação para cultivo de arroz e emergência de Anopheles arbitarsis na região sudeste do Brasil]. Rev. Saúde Pública, 27: 227-36, 1993. Apresentam-se os resultados obtidos mediante a coleta sistemática de formas imaturas de Culicidae levadas a efeito no sistema de irrigação artificial instalado na Estação Experimental do Vale do Ribeira, Estado de São Paulo, (Brasil), durante o período de janeiro a dezembro de 1992. Pôde-se verificar a existência de relação entre esse sistema e o estabelecimento de cria- 
douros. O estado de inundação dos campos de cultivo de arroz propiciou o desenvolvimento de representantes de Anopheles (Nyssorhynchus) e de Culex (Melanoconion). Por sua vez, o esvaziamento dessas áreas permitiu condições favoráveis para o desenvolvimento de Aedes scapularis e de representantes do Grupo Pilosus de Melanoconion s.g. graças a oviposições realizadas no terreno drenado. As poças produzidas pela água da chuva, favoreceram a criação de representantes de Culex (Culex), como $C x$. chidesteri, e de An. oswaldoi nas valas de drenagem. Tais resultados foram comparados com os obtidos em coletas realizadas concomitantemente em área mais primitiva da mesma região. Foi possível verificar que várias espécies apresentaram elevado grau de adaptabilidade ao ambiente humano. Mereceu atenção An. albitarsis como vetor potencial de malária e que revelou densidade de formas imaturas treze vezes maior no sistema irrigado do que no natural. Além desse mosquito, destacou-se comportamento análogo por parte de Ae. scapularis, An. oswaldoi, Cx. bastagarius e Cx. chidesteri, com elevados níveis de sinantropia.

Descritores: Ecologia de vetores. Anopheles . Aedes. $\mathrm{Cu}$ lex.Malária, transmissão.

\section{References}

1. BISSET, J.; MARQUETTT, M. del C.; NAVARRO, A.; GARCIA; A. Estudio de la densidad larval de Anopheles $(N)$ albimanus Wiedemann, 1821 en relacion con la fenologja del arroz Oryza sativa (Linnaeus). Rev. Cubana Med. Trop., 41:86-92, 1989.

2. BRITO, M. de A. Questōes associadas à evolução recente da agricultura brasileira. Rev. Bras. Geogr., 49:139-61, 1987.
3. FISHER, R.A.; CORBET, A.S.; WILLIAMS, C.D. The relation between the number of species and the number of individuals in a random sample for an animal population. J. Animal Ecol., 12:42-58, 1943.

4. FORATTINI, O.P.; GOMES, A. de C.; SANTOS, J.L.F.; GALATI, E.A.B.; RABELLO, E.X.; NATAL, D. Observaçōes sobre atividade de mosquitos Culicidae em mata residual no Vale do Ribeira, São Paulo, Brasil. Rev. Saúde Pública, 15:557-86, 1981.

5. FORATTINI, O.P.; GOMES, A. de C.; KAKITANI, I. Observações sobre mosquitos Culicidae adultos em cultivo irrigado de arroz no Vale do Ribeira, Estado de São Paulo, Brasil. Rev. Saúde Pública, 23:307-12, 1989.

6. FORATTINI, O.P.; KAKITANI, I.; MASSAD, E.; GOMES, A. de C. Studies on mosquitoes (Diptera: Culicidae) and anthropic environment. 1 - Parity of blood seeking Anopheles (Kerteszia) in south-eastem Brazil. Rev. Saúde Pública, 27: 1-8, 1993.

7. Instituto Oceanográfico (USP) S. Paulo Boletim climatológico. $n^{2}$. (6): p.1-6, 1989.

8. KELLER, E.C. de S. Atividade agrária. In: Fundação IBGE. Geografia do Brasil: regiäo sudeste. Rio de Janeiro, Dir. Divulgação, 1977. v. 3, p. 383-483.

9. LACEY, L.A. \& LACEY, C.M. The medical importance of riceland mosquitoes and their control using alternatives to chemical insecticides. J. Am. Mosq. Control Ass. (Suppl. 2): 1-93, 1990.

10. MATTINGLY, P.F. Mosquito eggs. XXVII - Culex subgenera Melanoconion and Mochlostyrax. Mosq. Syst., 8:223-31, 1976.

11. POVOLNY, D. Synanthropy. In : Greenberg, B. ed. Flies and disease. New Jersey, Princeton University Press, 1971.v.1.

12. SERVICE, M.W. Rice, a challenge to health. Parasitol. Today, 5:162-5, 1989.

Recebido para publicação em 23.3.1993 Aprovado para publicação em 23. 7. 1993 